\title{
Effects of electrolytes on virus inactivation by acidic solutions
}

\author{
MITSUNORI NISHIDE $^{1}$, KAZUKO TSUJIMOTO ${ }^{1}$, MISAO UOZAKI $^{1}$, KEIKO IKEDA $^{1}$, \\ HISASHI YAMASAKI ${ }^{1}$, A. HAJIME KOYAMA ${ }^{1}$ and TSUTOMU ARAKAWA ${ }^{2}$ \\ ${ }^{1}$ Division of Virology, Department of Cellular and Molecular Medicine, Wakayama Medical University \\ Graduate School of Medicine, Wakayama 641-0011, Japan; ${ }^{2}$ Alliance Protein \\ Laboratories, 3957 Corte Cancion, Thousand Oaks, CA 91360, USA
}

Received November 18, 2010; Accepted January 10, 2011

DOI: $10.3892 / \mathrm{ijmm} .2011 .668$

\begin{abstract}
Acidic $\mathrm{pH}$ is frequently used to inactivate viruses. We have previously shown that arginine synergizes with low $\mathrm{pH}$ in enhancing virus inactivation. Considering a potential application of the acid inactivation of viruses for the prevention and treatment of superficial virus infection at body surfaces and fixtures, herein we have examined the effects of various electrolytes on the acid-induced inactivation of the herpes simplex virus type 1 (HSV-1) and type 2 (HSV-2), the influenza $\mathrm{A}$ virus (IAV) and the poliovirus upon their incubation at $30^{\circ} \mathrm{C}$ for $5 \mathrm{~min}$. Eight electrolytes, i.e., phosphate, $\mathrm{NaCl}$, glutamate, aspartate, pyrrolidone carboxylate, citrate, malate and acetate were tested. No detectable inactivation of the poliovirus was observed under the conditions examined, reflecting its acid-resistance. HSV-1 and HSV-2 responded similarly to the acid-treatment and electrolytes. Some electrolytes showed a stronger virus inactivation than others at a given $\mathrm{pH}$ and concentration. The effects of the electrolytes were virus-dependent, as IAV responded differently from HSV-1 and HSV-2 to these electrolytes, indicating that certain combinations of the electrolytes and a low $\mathrm{pH}$ can exert a more effective virus inactivation than other combinations and that their effects are virus-specific. These results should be useful in designing acidic solvents for the inactivation of viruses at various surfaces.
\end{abstract}

\section{Introduction}

Virus inactivation is a critical technology for both the prevention of virus infection $(1,2)$ and the development of pharmaceutical

Correspondence to: Dr A. Hajime Koyama, Division of Virology, Department of Cellular and Molecular Medicine, Wakayama Medical University Graduate School of Medicine, Wakayama 641-0011, Japan

E-mail: koyama@wakayama-med.ac.jp

Dr Tsutomu Arakawa, Alliance Protein Laboratories, 3957 Corte Cancion, Thousand Oaks, CA 91360, USA

E-mail: tarakawa2@aol.com

Key words: virus inactivation, acid, electrolyte, disinfectant proteins $(3,4)$. Daily preventive measures, such as disinfection of various contaminated-surfaces that come in contact with humans, reduces the chance of acquiring infectious diseases (5-8). Such preventive measures are normally accomplished by the application of acidic solutions (2,7-10) or disinfectants $(5,11,12)$ that inactivate the viruses present on contaminated surfaces or on human fingers and hands. Virus inactivation is also a critical process for manufacturing therapeutic proteins when produced based on mammalian-derived cell lines, which may contain infectious viruses. Unfortunately, acids and disinfectants can be severely toxic to cells and tissues or can damage pharmaceutical proteins under the conditions sufficient to inactivate viruses. These factors limit the practical applications of acidic solutions in virus inactivation (10,12-16). Alternatively, the acidic solutions alone may be insufficiently effective against certain viruses (2). Thus, the development of a safer and more effective treatment is a valuable weapon against virus infection.

We have previously shown that arginine synergizes with a low $\mathrm{pH}$ in virus inactivation (17-20). In other words, it is not just the acidic conditions that play a role in virus inactivation, but the presence of electrolytes, arginine in the above case, can modulate the efficacy of acidic solutions to inactivate viruses. In the present study, we have examined various electrolytes, including amino acids, organic and inorganic acids and salt, in modulating the acid-induced inactivation of four different viruses with different virion structures and replication strategies. Even a small degree of enhanced virus inactivation over the acidic solutions should provide an advantage in reducing the chance for a virus infection.

\section{Materials and methods}

Reagents. Solvents for virus inactivation were prepared by titrating each aqueous solution of organic, inorganic, and amino acids at room temperature with a $4 \mathrm{M}$ aqueous sodium hydroxide solution. The $\mathrm{pH}$ of each solvent was adjusted to the desired values using the $\mathrm{pH}$ electrode 6378 and the $\mathrm{pH}$ meter F-54 (Horiba; Kyoto, Japan). The $\mathrm{pH}$ meter was manually calibrated every $2 \mathrm{~h}$ during solvent preparation. Citric and malic acid were purchased from Nacalai Tesque (Kyoto, Japan). Sodium chloride $(\mathrm{NaCl})$, acetic acid and sodium dihydrogen phosphate dihydrate were purchased from 
Junsei Chemical Co., Ltd (Tokyo, Japan). Sodium pyrrolidone carboxylate, aspartic acid (Asp), and glutamic acid (Glu) were kindly provided by Ajinomoto Co., Inc. (Tokyo, Japan). All chemicals were of biochemical research grade.

Cells and viruses. Vero and MDCK cells were grown in Eagle's minimum essential medium (MEM) containing 5\% fetal bovine serum (FBS). The Herpes simplex virus type 1 strain $F$ (HSV-1) and type 2 strain 186 (HSV-2), the influenza virus A/ Aichi/ $68 \mathrm{H}_{3} \mathrm{~N}_{2}$ (IAV) and the poliovirus type 1 Sabin vaccine strain (PV-1) were used throughout the experiments. The viruses were propagated in Vero cells in MEM supplemented with $0.5 \%$ FBS for HSV-1, HSV-2 and PV-1 or in MDCK cells in MEM supplemented with $0.1 \%$ bovine serum albumin (BSA) and acetylated trypsin $(5.3 \mu \mathrm{g} / \mathrm{ml})$ for IAV and stored at $-80^{\circ} \mathrm{C}$ until use. The amount of virus was measured by a plaque assay on Vero or MDCK cells as described previously (21-23).

Assay for virucidal activity. All the starting materials were stored on ice prior to the virus inactivation experiments. An excess volume of solvents was mixed with the virus stock so that the $\mathrm{pH}$ of the electrolyte solutions would not be affected: i.e., a $190 \mu 1$ aliquot of the electrolyte solutions received a $10 \mu 1$ aliquot of virus preparations (approximately $10^{7} \sim 10^{8}$ plaque-forming units $(\mathrm{PFU}) / \mathrm{ml})$. This virus preparation was incubated at $30^{\circ} \mathrm{C}$ for $5 \mathrm{~min}$. After incubation, aliquots of these virus samples were diluted 100-fold with ice-cold Dulbecco's phosphate-buffered saline (PBS) without $\mathrm{Ca}^{2+}$ and $\mathrm{Mg}^{2+}$ containing $0.1 \% \mathrm{BSA}$ for IAV or $0.5 \% \mathrm{FBS}$ for other viruses to quench the virus inactivation. The viruses were further diluted to yield virus counts suitable for measurements and the number of infectious virus in the treated preparation was measured by a plaque assay. Virus inactivation in PBS was insignificant and hence the amount of infectious virus in PBS was used as a control count.

\section{Results}

The basal levels of virus inactivation were assessed using $10 \mathrm{mM}$ citrate, $0.15 \mathrm{M} \mathrm{NaCl}$ at a pH of 3.8-6.0. Namely, HSV-1, HSV-2, IAV and PV-1 were exposed to the low $\mathrm{pH}$ solutions at $30^{\circ} \mathrm{C}$ for $5 \mathrm{~min}$. This temperature was chosen to simulate the temperature of the surfaces or fixtures of the human body. The $\mathrm{pH}$-dependence of the virus inactivation for these four viruses is shown in Fig. 1A. Both HSV-1 and HSV-2 were significantly inactivated below $\mathrm{pH} 4.6$ followed by a sharp decline in relative infectivity below $\mathrm{pH}$ 4.0. The $\mathrm{pH}$-dependence of the virus inactivation for HSV-1 and HSV-2 was similar, both with no detectable virus recovery at $\mathrm{pH} 3.8$ and with a modest inactivation above $\mathrm{pH}$ 4.0. Such similarity may be due to their similar virion surface properties. Conversely, IAV showed a significant virus inactivation at $\mathrm{pH} 5.0$ with nearly a one $\log$ reduction in relative infectivity. PV-1 showed no apparent inactivation even at $\mathrm{pH} 3.8$, as expected from its acid resistance (24). Specifically, PV-1 replicates in the alimentary tract through its transmission by the fecal-oral route, which is made possible due to its resistance to acidic conditions in the stomach (24). Considering that PV-1 is a non-enveloped virus, the observed inactivation of HSV-1, HSV-2 and IAV, which are all enveloped viruses, by the acidic solutions suggests the
Table I. Dissociation constants of electrolytes.

\begin{tabular}{lcc}
\hline Electrolyte & $\mathrm{pK} 1$ & $\mathrm{pK} 2$ \\
\hline Phosphoric acid & 2.14 & 7.1 \\
$\mathrm{NaCl}$ & $\mathrm{NA}$ & $\mathrm{NA}$ \\
Glutamic acid (Glu) & 2.19 & 4.25 \\
Citric acid & 3.12 & 4.76 \\
Aspartic acid (Asp) & 1.88 & 3.65 \\
Malic acid & 3.40 & 5.11 \\
Pyrrolidone carbonic acid (PCA) & 3.32 & \\
Acetic acid & 4.74 & \\
\hline
\end{tabular}

NA, not applicable.

involvement of the lipid membranes present in these viruses. It is thus, evident that the viruses respond differently to acidic pHs.

The variation of the virus response to low $\mathrm{pH}$ is plotted in Fig. 1B. At pH 3.8, all three enveloped viruses were inactivated to a level below the detection limit of the virus counts under the experimental conditions used. As stated above, no inactivation was observed for PV-1. In response to treatment at a pH 4.0 (just $0.2 \mathrm{pH}$ unit higher), only one log reduction of the relative infectivity was observed for HSV-1 and HSV-2, a large difference from the observed effect of this $\mathrm{pH}$ on IAV. IAV was much more sensitive to low pH than HSV-1 and HSV-2. Similar results were obtained at $\mathrm{pH} 5.0$, at which $\mathrm{pH}$ only a marginal inactivation was observed for HSV-1 and HSV-2 and a small, but significant, inactivation occurred for IAV.

We next examined the efficacy of the combination of a low $\mathrm{pH}$ and various electrolytes, i.e., phosphoric acid, $\mathrm{NaCl}$, acetic, citric and malic acids, Glu, pyrrolidone carbonic acid (PCA) and Asp. As all these, except for $\mathrm{NaCl}$, are weak electrolytes they have at least one dissociable group as shown in Table I. When these eight different acidic solutions containing $0.15 \mathrm{M}$ electrolytes (or $0.095 \mathrm{M}$ for Glu and Asp due to their low solubility) in the presence of $10 \mathrm{mM}$ citrate were assessed on HSV-1, HSV-2, IAV and PV-1, no inactivation was observed for PV-1 by any of these combinations. Fig. 2 shows the $\mathrm{pH}$-dependence of the relative infectivity for HSV-1 (Fig. 2A) and HSV-2 (Fig. 2B). These eight electrolytes were essentially grouped into three classes based on their $\mathrm{pH}$ dependence: circles for $0.15 \mathrm{M}$ phosphate, $0.15 \mathrm{M} \mathrm{NaCl}$ and $0.095 \mathrm{M}$ Glu (Group-1), triangles for $0.15 \mathrm{M}$ malate, $0.15 \mathrm{M}$ PCA, $0.095 \mathrm{M}$ Asp and $0.15 \mathrm{M}$ citrate (Group-2), and squares for acetate. In other words, the first three electrolytes (i.e., phosphate, $\mathrm{NaCl}$ and $\mathrm{Glu}$ ) showed little inactivation for HSV-1 even at the $\mathrm{pH} 4.0$, below which a sharp decline in the relative infectivity was observed at a level of $10^{-5}$ or less at $\mathrm{pH} 3.8$. These electrolytes are thus weak in HSV-1 inactivation. The next four electrolytes (i.e., malate, PCA, Asp and citrate) showed a significant inactivation of HSV-1 at $\mathrm{pH} 4.2$, below which a sharp decline was observed. It is evident that these four electrolytes (Group-2) have a stronger effect on HSV-1 inactivation than phosphate, $\mathrm{NaCl}$ and $\mathrm{Glu}$ (Group-1). The $\mathrm{pH}$-dependence of acetate qualitatively differed from the 

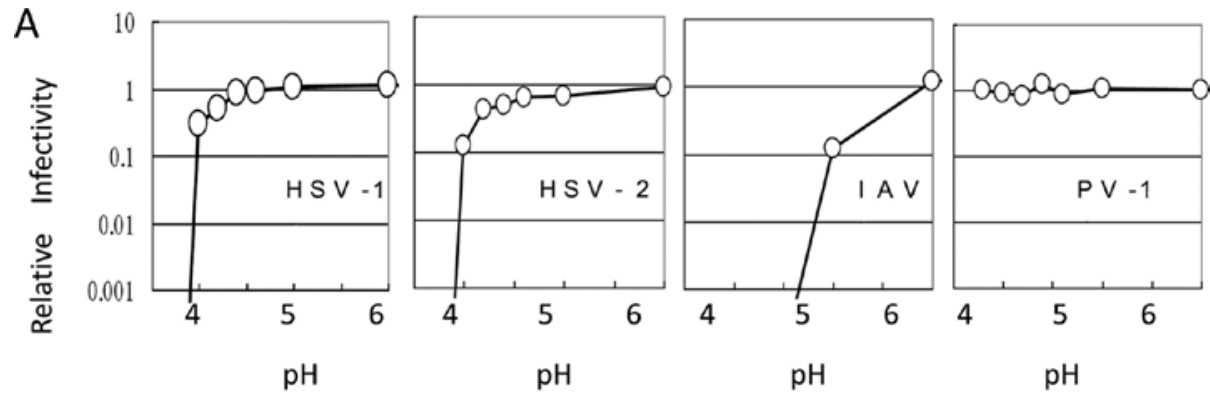

B

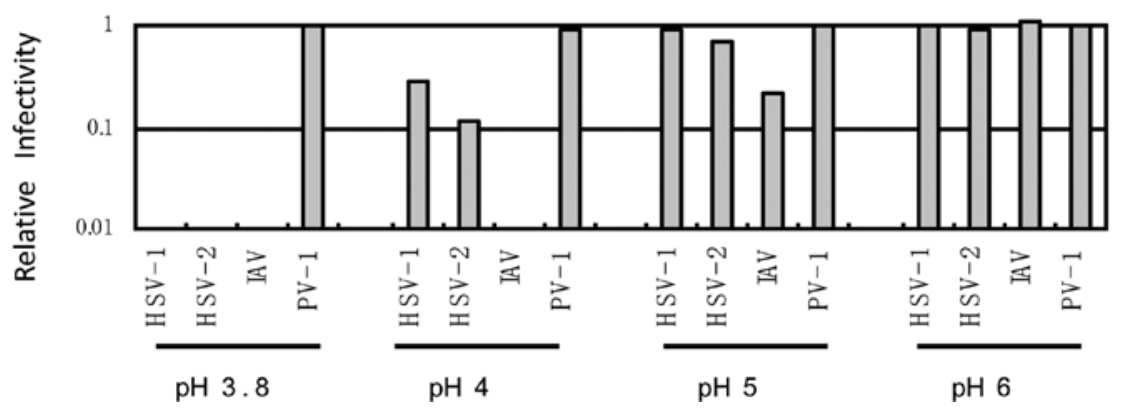

Figure 1. Inactivation of viruses at various $\mathrm{pH}$ values. The viruses were incubated at $30^{\circ} \mathrm{C}$ for $5 \mathrm{~min}$ in $10 \mathrm{mM}$ citrate-buffer, $0.15 \mathrm{M} \mathrm{NaCl}$, at different $\mathrm{pHs}$. The number of infectious viruses was determined by a plaque assay after incubation and was normalized to that with incubation in PBS (pH 7.4). (A) Relative infectivity of HSV-1, HSV-2, IAV and PV-1 as a function of $\mathrm{pH}$. (B) Comparison of the relative infectivity of the four viruses at pHs 3.8, 4.0, 5.0 and 6.0.
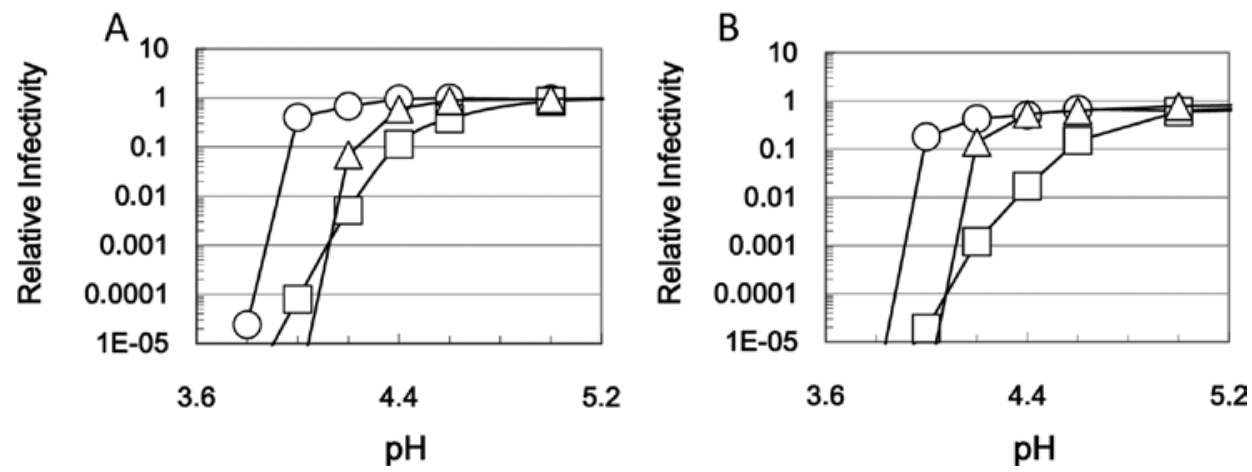

Figure 2. Inactivation of HSV-1 (A) and HSV-2 (B) in the presence of different electrolytes. The virus was incubated with the electrolytes, all containing $10 \mathrm{mM}$ citrate, at the indicated $\mathrm{pH}$ for $5 \mathrm{~min}$ at $30^{\circ} \mathrm{C}$. The number of infectious viruses was determined by a plaque assay after the incubation in electrolyte and was normalized to that of incubation in PBS (pH 7.4). Circles (O) denote $0.15 \mathrm{M}$ phosphate, $0.15 \mathrm{M} \mathrm{NaCl}$ and $0.095 \mathrm{M}$ glutamate; triangles ( $\triangle$ ), $0.15 \mathrm{M}$ citrate, $0.15 \mathrm{M}$ malate, $0.15 \mathrm{M}$ PCA and $0.095 \mathrm{M}$ aspartate; squares (), $0.15 \mathrm{M}$ acetate.

above seven electrolytes. There was a significant inactivation already with this electrolyte at $\mathrm{pH} 4.4$, at which $\mathrm{pH}$ the other seven electrolytes were barely effective. However, the $\mathrm{pH}$-dependence was much weaker with this electrolyte, leading to a lower inactivation effectiveness at $\mathrm{pH} 4.0$ than the Group- 2 electrolytes (depicted by triangles). Acetate was stronger than phosphate, $\mathrm{NaCl}$ and $\mathrm{Glu}$ (Group-1) at any $\mathrm{pH}$ examined. A similar trend was observed with HSV-2 (Fig. 2B). Phosphate, $\mathrm{NaCl}$ and Glu required a lower $\mathrm{pH}$ than others to achieve the same level of virus inactivation. Acetate showed a lower $\mathrm{pH}$-dependence, leading to a greater inactivation above $\mathrm{pH} 4.2$ than other electrolytes, but a lower effectiveness at pH 4.0 than Group-2 electrolytes (triangles).

The eight electrolytes behaved differently against IAV, although they also appeared to be grouped into three classes. As shown in Fig. 3, phosphate and Glu (shown by circles) showed the weakest inactivation, similarly to their effects on HSV-1 and HSV-2. Interestingly, their effects leveled off at $\mathrm{pH} 4$.6, instead of reaching the undetectable relative infectivity as the $\mathrm{pH}$ was further reduced. The middle group consisting of five electrolytes, i.e., $\mathrm{NaCl}$, acetate, citrate, malate and PCA (triangles) showed a monotone decrease with $\mathrm{pH}$ in infectivity. In other words, the leveling-off of the inactivation was not observed for these five electrolytes. Their effects were intermediate at $\mathrm{pH} 5.0$, but were the strongest below $\mathrm{pH} 4.4$ due to the linear $\mathrm{pH}$-dependent virus inactivation. Asp (diamonds) was more effective than the other seven electrolytes at a higher $\mathrm{pH}$, but leveled off at $\mathrm{pH} 5.0$, similarly to phosphate and Glu. It is not clear why these electrolytes (phosphate, Glu and Asp) showed a plateau in the inactivation of IAV. Such plateau is specific for IAV, as HSV-1 and HSV-2 showed no such tendency. There may be a specific interaction between 


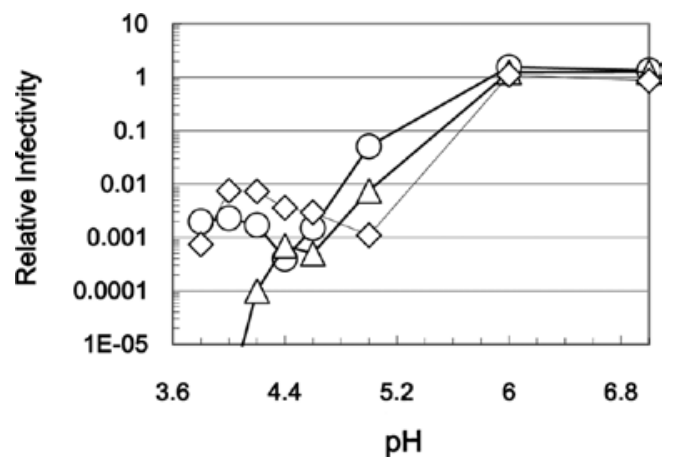

Figure 3. Inactivation of IAV in the presence of different electrolytes. IAV was incubated with the electrolytes, all containing $10 \mathrm{mM}$ citrate, at the indicated $\mathrm{pH}$ for $5 \mathrm{~min}$ at $30^{\circ} \mathrm{C}$. The number of infectious viruses was determined by a plaque assay after the incubation in electrolyte and was normalized to that of incubation in PBS (pH 7.4). Circles (O) denote $0.15 \mathrm{M}$ phosphate and $0.095 \mathrm{M}$ glutamate; triangles $(\triangle), 0.15 \mathrm{M} \mathrm{NaCl}, 0.15 \mathrm{M}$ acetate, $0.16 \mathrm{M}$ citrate, $0.15 \mathrm{M}$ malate and $0.15 \mathrm{M}$ PCA; diamonds $(\diamond), 0.095 \mathrm{M}$ aspartate.

IAV and these three electrolytes (phosphate, Glu and Asp) that stabilize IAV against low $\mathrm{pH}$-induced virus inactivation.

Next, the effects of the concentration of the electrolytes were examined for acetate and citrate at $\mathrm{pH} 4.2$ and 4.4, $\mathrm{pHs}$ at which they showed moderate inactivation of HSV-1 (Fig. 4A) and HSV-2 (Fig. 4B). As shown in Fig. 4A, at $\mathrm{pH} 4.2$, no increase in the virus inactivation was observed with acetate up to $0.6 \mathrm{M}$ (open circles), above which a sharp increase in inactivation to the detection limit was observed. No such concentration-dependence was observed for acetate at $\mathrm{pH} 4.4$ (open triangles). Citrate at $0.15 \mathrm{M}$ was less effective than acetate at both pHs and became even more less effective at higher concentrations. Namely, a small, but significant, inactivation effect that was apparent at $0.15 \mathrm{M}$ diminished with increasing concentration at $\mathrm{pH} 4.2$ (closed circles). Essentially no virus inactivation was observed for citrate at $\mathrm{pH} 4.4$ in the entire range of concentrations (0.15-0.9 M, closed triangles).

As shown in Fig. 4B, concentration-dependence for acetate was more apparent with HSV-2 (open symbols). The virus inactivation sharply increased with acetate concentration at $\mathrm{pH} 4.2$, leading to undetectable virus counts at $0.6 \mathrm{M}$ (open circles). Only marginal concentration-dependence was observed at pH 4.4 (open triangles). Similar to HSV-1, increased concentration abolished a small inactivation effect of citrate on HSV-2 at pH 4.2 (closed circles). Citrate was ineffective at $\mathrm{pH} 4.4$ at any concentration (closed triangles). Thus, it is evident that while the effectiveness of virus inactivation for both HSV-1 and HSV-2 increases with concentration for acetate, at $\mathrm{pH} 4.2$, it decreases for citrate.

We also examined the effects of $\mathrm{NaCl}$ and phosphate on HSV-1 and HSV-2 inactivation as a function of concentration. However, these two electrolytes showed little virus inactivation at any electrolyte concentrations, although inactivation was slightly enhanced at $0.9 \mathrm{M}$ (data not shown).

IAV responded to increasing concentrations of acetate differently. Such dependence for acetate is shown in Fig. 5A (open symbols). At both $\mathrm{pH} 4.2$ and 4.4, the virus inactivation at $0.3 \mathrm{M}$ (open circles and triangles) was so effective that the virus recovery was below the limit of detection. At $\mathrm{pH} 5.0$ (open squares), the dose-dependence curve was shifted upward, meaning that the effectiveness significantly decreased at any acetate concentrations below $0.6 \mathrm{M}$. Nevertheless, it was evident that the effects saturated at $0.6 \mathrm{M}$, above which concentration the virus recovery reached the detection limit. Interestingly, citrate also showed dose-dependent inactivation at $\mathrm{pH} 4.2$ and 4.4 (closed circles and triangles). At pH 4.2, $0.3 \mathrm{M}$ citrate resulted in virus inactivation to the detection limit, similarly to what was observed with acetate at $\mathrm{pH} 4.2$. Virus inactivation efficacy of citrate was significantly reduced at $\mathrm{pH} 4.4$ between 0.3 and $0.6 \mathrm{M}$, but reached the detection limit at $0.9 \mathrm{M}$. However, at $\mathrm{pH} 5.0$ (closed squares), the concentration-dependence was opposite to the results at $\mathrm{pH} 4.2$ and 4.4. The efficacy of citrate at this $\mathrm{pH}$ decreased with increasing concentration.

The concentration-dependence of IAV inactivation was also examined for $\mathrm{NaCl}$ (closed symbols) and phosphate (open symbols) (Fig. 5B). NaCl at pH 4.2 (closed circles) and 4.4 (closed triangles) was highly effective, reaching the maximum efficacy at $0.3 \mathrm{M}$. However, $\mathrm{NaCl}$ was totally ineffective at pH 5.0 at any concentration (closed squares). Phosphate showed completely different concentration-dependence. At any $\mathrm{pH}$ between 4.2-5.0, concentration increases slightly, though significantly, reduced the virus inactivation effects of this electrolyte (open circles, triangles and squares).

The comparison of the effects of $\mathrm{NaCl}$, phosphate, citrate and acetate on the inactivation of IAV at $\mathrm{pH} 5.0$ under the
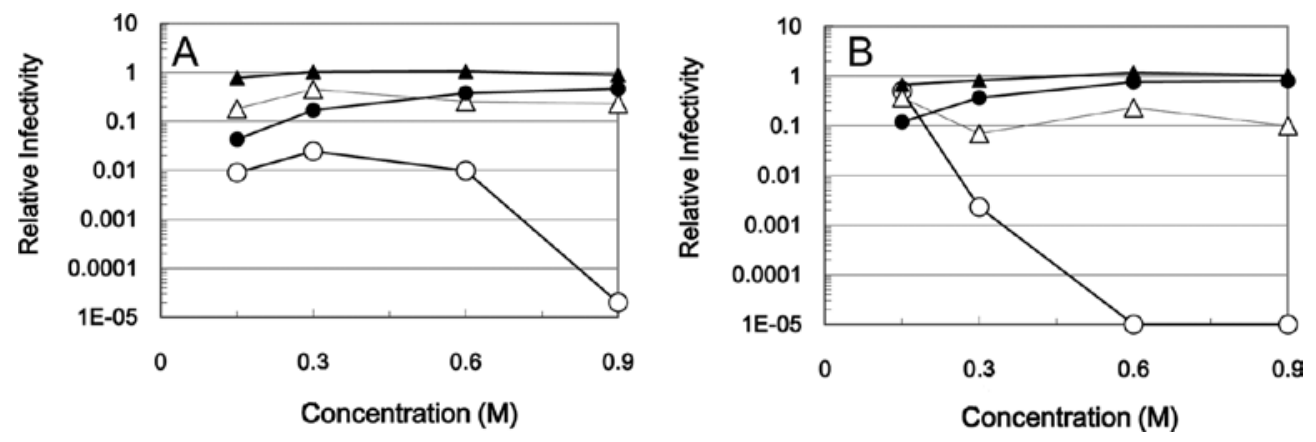

Figure 4. Effects of electrolyte-concentration on the inactivation of HSV-1 (A) and HSV-2 (B) at different pHs. The virus was incubated with the electrolytes, all containing $10 \mathrm{mM}$ citrate, at the indicated $\mathrm{pH}$ for $5 \mathrm{~min}$ at $30^{\circ} \mathrm{C}$. Open symbols $(\mathrm{O}, \triangle)$ denote $0.15 \mathrm{M}$ acetate; closed symbols $(\bullet, \mathbf{\Delta}), 0.15 \mathrm{M}$ citrate. Circles, $\mathrm{pH} 4.2$; triangles, $\mathrm{pH}$ 4.4. The number of infectious viruses was determined by a plaque assay after the incubation in electrolyte and was normalized to that of incubation in PBS (pH 7.4). 

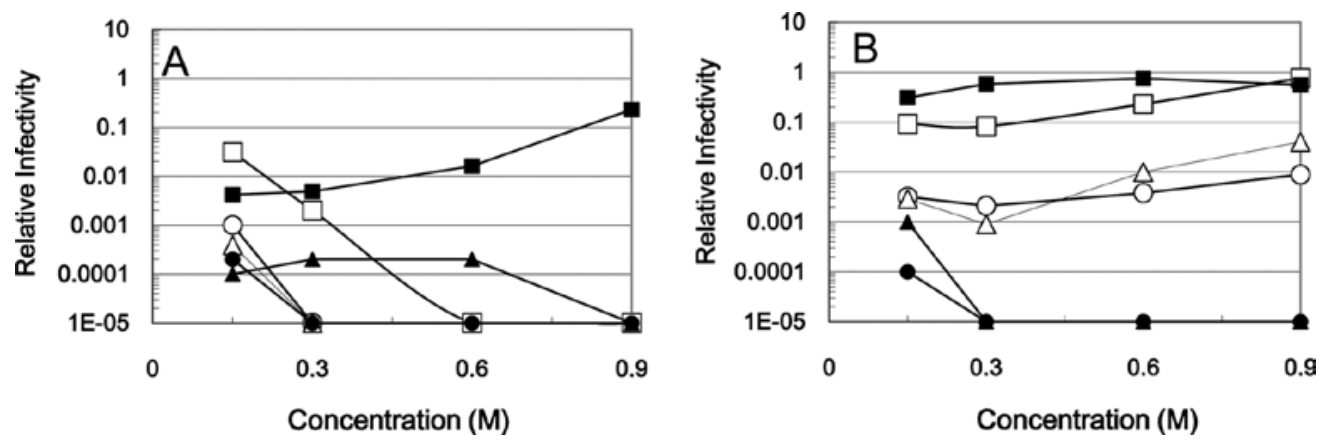

Figure 5. Effects of electrolyte-concentration on IAV inactivation at different pHs. (A), IAV incubation with $0.15 \mathrm{M}$ acetate $(\mathrm{O}, \triangle, \square)$ or $0.15 \mathrm{M}$ citrate $(\mathbf{\bullet}, \mathbf{\Delta}, \mathbf{\square})$ at $\mathrm{pH} 4.2(\mathrm{O}, \bullet), \mathrm{pH} 4.4(\triangle, \mathbf{\Delta})$ or $\mathrm{pH} 5.0(\square, \boldsymbol{\square})$ for $5 \mathrm{~min}$ at $30^{\circ} \mathrm{C}$. (B), virus incubation with $0.15 \mathrm{M}$ phosphate $(\mathrm{O}, \Delta, \square)$ or $0.15 \mathrm{M} \mathrm{NaCl}(\bullet, \mathbf{\Delta}, \mathbf{\square})$ at pH $4.2(\mathrm{O}, \bullet)$, $\mathrm{pH} 4.4(\triangle, \mathbf{\Lambda})$ or $\mathrm{pH} 5.0(\square, \mathbf{\square})$ for $5 \mathrm{~min}$ at $30^{\circ} \mathrm{C}$. All the electrolyte solutions contained $10 \mathrm{mM}$ citrate. The number of infectious viruses was determined by a plaque assay after the incubation in electrolyte and was normalized to that of incubation in PBS (pH 7.4).

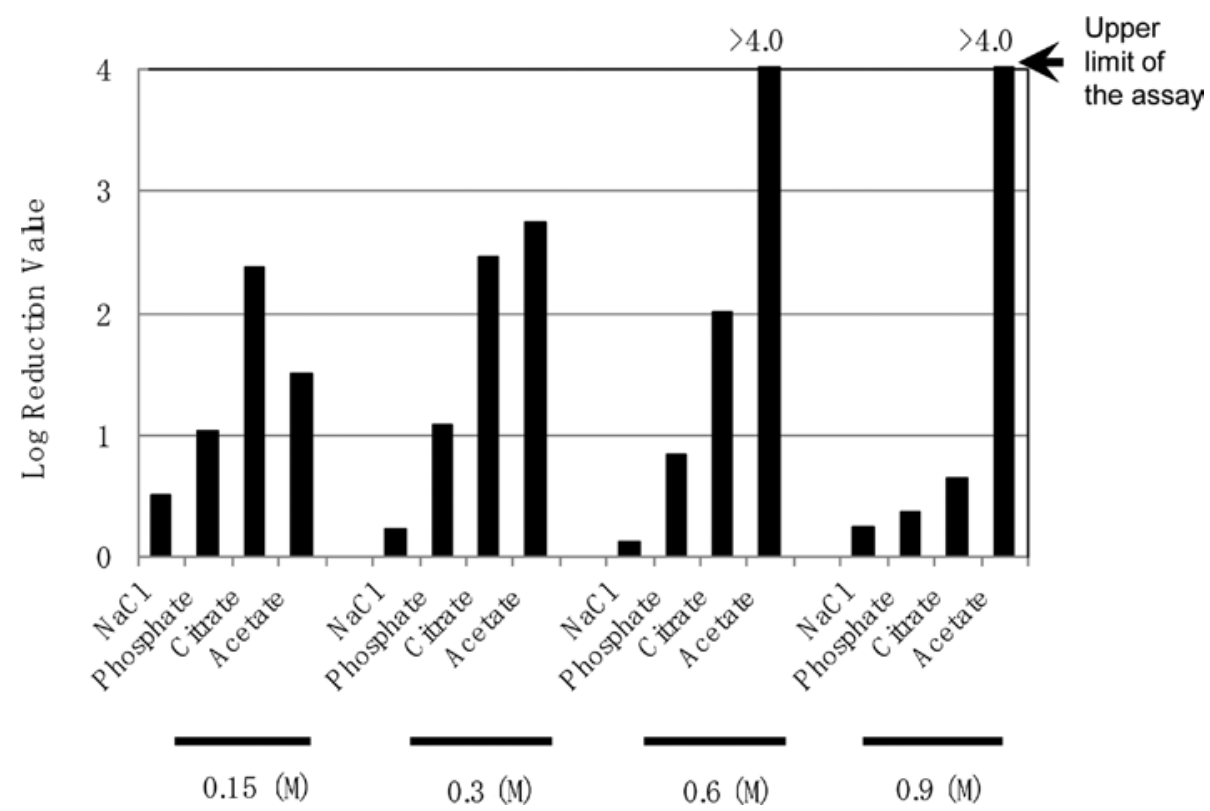

Figure 6. Comparison of the effects of the electrolytes on IAV inactivation at $\mathrm{pH}$ 5.0. IAV was incubated with NaCl, phosphate, citrate or acetate at $0.15 \mathrm{M}$, $0.30 \mathrm{M}, 0.60 \mathrm{M}$ or $0.90 \mathrm{M}$ concentrations for $5 \mathrm{~min}$ at $30^{\circ} \mathrm{C}$. All the electrolyte solutions were at $\mathrm{pH} 5.0$ and contained $10 \mathrm{mM}$ citrate. Log reduction value $(\mathrm{LRV})$ was calculated by $\mathrm{LRV}=\log$ (virus recovery in PBS/virus recovery in the test solvent).

different electrolyte-concentrations is shown in Fig. 6. $\mathrm{NaCl}$ was the least effective at any concentration followed by phosphate. Interestingly, $0.15 \mathrm{M}$ citrate was more effective than $0.15 \mathrm{M}$ acetate. However, citrate was less effective than acetate at higher concentrations, in particular above $0.6 \mathrm{M}$, where acetate became extremely effective in inactivating IAV to the detection limit.

\section{Discussion}

The most critical information obtained from this study is that virus inactivation is a function of not only the $\mathrm{pH}$ but also of the type and the concentration of the electrolyte. We have previously shown that arginine synergizes with the $\mathrm{pH}$ conditions in inactivating HSV-1, HSV-2 and IAV (17-20). As shown in Fig. 1B, the virus inactivation was weak at $\mathrm{pH} 4.0$ by acid alone. The addition of arginine concentration dependently increased the virus inactivation at this $\mathrm{pH}$
(17-20). We have ascribed this to the effects of arginine on protein-protein or protein-lipid interactions, as arginine has been shown to suppress protein aggregation and lipid assembly (25-38). A similar observation was made here with various electrolytes. Certain combinations of electrolytes and a low $\mathrm{pH}$ resulted in a greater virus inactivation than other combinations. Furthermore, the effects of the electrolytes were shown to be virus-dependent (Figs. 2 and 3). In regards to HSV-1 and HSV-2, the effects of the electrolytes were also concentration-dependent with the efficacy increasing for one electrolyte and decreasing for the other as the concentration increased (Fig. 4). Therefore, it appears essential that different electrolytes be screened for their efficacy against each virus as a function of $\mathrm{pH}$ and concentration. This is most clearly demonstrated with the case of IAV (Fig. 5). In addition, we have demonstrated that there is no point in using excessively low $\mathrm{pH}$ when combined with phosphate, Glu and Asp, whose effects leveled off at $\mathrm{pH}$ 4.6-5.0 (Fig. 3). 
Why are the effects of the electrolytes different from each other? There are a number of reasons. First, most of the electrolytes tested are weak electrolytes with at least one dissociable group (pK), as listed in Table $\mathrm{I}$. $\mathrm{NaCl}$ is the only strong electrolyte examined. This means that the ratio of uncharged to charged species varies with the $\mathrm{pH}$ value and that the $\mathrm{pH}$ dependence of the ratio and hence the ionic strength of the solution differs from one electrolyte to the other. However, there is no simple relation between the $\mathrm{pK}$ value and the effectiveness of virus inactivation. For example, the virus inactivation effectiveness of citrate diminishes with increasing concentration for HSV-1 and HSV-2, which may be ascribed to the protein stabilization effects of this electrolyte $(39,40)$. Thus, the pK of weak electrolytes cannot be used to explain the observed differences between the electrolytes. Nevertheless, the pK may play a critical role in maintaining the $\mathrm{pH}$ upon mixing the electrolyte solutions with the viruses, which possess solvent-exposed charged groups on the virion surface.

How do electrolytes affect viruses? At low concentrations, ions form electrical double layers around the charged particles and screen their charges $(41,42)$. Since the viruses are more positively charged as the $\mathrm{pH}$ is lowered, the ions from the electrolytes would shield their surface charges, leading to virus stabilization that may offset the inactivation effects of low $\mathrm{pH}$. Such charge screening effects should depend on the ionic strength and hence the $\mathrm{pK}$ and also the type of the ions (e.g., the size and valency of the ions). At high concentrations, additional effects of the electrolytes should occur. One such effect is on the water structure. Cohesive force of the electrolytes on the water molecules often correlates with their stabilizing effects on macromolecular solutes $(43,44)$ and hence may stabilize the viruses. Another effect that may occur at high electrolyte concentration is acid binding. Either the ionic or the neutral forms of the electrolytes may weakly bind to the viruses, which would alter the surface properties of the viruses and may stabilize or may destabilize the viruses. As each of these effects may depend on both the electrolytes and the viruses, it appears that screening of the electrolytes for the target virus is essential in finding the most effective combination of the electrolyte and low $\mathrm{pH}$.

PV-1 exhibited resistance to both the acidic solutions and to the electrolytes tested, consistent with the reported results $(24,45)$. Such resistance was ascribed at least in part to the lack of a lipid membrane for this virus. However, there are certain non-enveloped viruses that are sensitive to acid treatment, for example, rhinoviruses (24). The vaccine strain of PV-1 has been observed to respond to temperature-induced inactivation treatment (24). Thus, understanding why certain non-enveloped viruses are sensitive to low $\mathrm{pH}$ and why PV-1 is sensitive to temperature may lead to a more rational approach for acid-induced inactivation of this virus in combination with certain electrolytes or other compounds (e.g., non-toxic organic solvents).

Another factor that must be considered is the type of applications for the electrolytes. For pharmaceutical applications, the electrolytes need to be removed from the final product or to be compatible with the administration. For surface disinfection (e.g., body surfaces, food hygiene and sanitizing fixtures), the electrolyte solutions should maintain the efficacy for a prolonged period. The stability of the electrolytes at the surface may be a critical factor for such applications.

\section{Acknowledgements}

The authors thank Dr Daiske Ejima (Ajinomoto Co. Inc.) for stimulating discussions.

\section{References}

1. Turner RB and Handley JO: Virucidal hand treatments for prevention of rhinovirus infection. J Antimicrob Chemother 56: 805-807, 2005.

2. Gern JE, Mosser AG, Swenson CA, Rennie PJ, England RJ, Shaffer J and Mizoguchi H: Inhibition of rhinovirus replication in vitro and in vivo by acid-buffered saline. J Infect Dis 195: 1137-1143, 2007.

3. Preuss T, Kamstrup S, Kyvsgaard NC, Nansen P, Miller A and Lei JC: Comparison of two different methods for inactivation of viruses in serum. Clin Diagn Lab Immunol 4: 504-508, 1997.

4. Brorson K and Norling L: Current and future approaches to ensure the viral safety of biopharmaceuticals. Dev Biol 118: 17-29, 2004.

5. Cone RA, Hoen T, Wong X, Abusuwwa R, Anderson DJ and Moench TR: Vaginal microbicides: detecting toxicities in vivo that paradoxically increase pathogen transmission. BMC Infect Dis 6: 90-105, 2006.

6. Halder J, An D, de Cienfuegos LA, Chen J and Klibanov AM: Polymeric coatings that inactivate both influenza virus and pathogenic bacteria. Proc Natl Acad Sci USA 103: 17667-17671, 2006.

7. Tsujimoto K, Uozaki M, Ikeda K, Yamasaki H, Utsunomiya H, Ichinose M, Koyama AH and Arakawa T: Solvent-induced virus inactivation by acidic solution. Int J Mol Med 25: 433-437, 2010

8. Ikeda K, Yamasaki H, Suzuki Y, Koyama AH and Arakawa T: Novel strategy with acidic arginine solution for the treatment of influenza A virus inactivation (Review). Exp Ther Med 1: 251-256, 2010.

9. Turner RB, Biedermann KA, Morgan JM, Keswick B, Ertel KD and Barker MF: Efficacy of organic acids in hand cleansers for prevention of rhinovirus infections. Antimicrob Agents Chemother 48: 2595-2598, 2004.

10. Rennie P, Bowtell P, Hull D, Charbonneau D, LambkinWilliams R and Oxford J: Low pH intranasal sprays inactivate influenza viruses in vitro and protect ferrets against influenza infection. Respir Res 8: 38-44, 2007.

11. Apel-Paz M, Doncel GF and Vanderlick TK: Membrane perturbation by surfactant candidates for STD prevention. Langmuir 19: 591-597, 2003.

12. Patnayak DP, Prasad AM, Malik YS, Ramakrishnan MA and Goyal SM: Efficacy of disinfectants and hand sanitizers against respiratory viruses. Avian Dis 52: 199-202, 2008.

13. Wanaratana S, Tantilertcharoen R, Sasipreeyajan and Pakpinyo S: The inactivation of avian virus subtype H5N1 isolated from chickens in Thailand by chemical and physical treatments. Vet Microbiol 140:43-48, 2010.

14. Grayson ML, Melvani S, Druce J, Barr IG, Ballard SA, Johnson PD, Mastorakos T and Birch C: Efficacy of soap and water and alcohol-based hand-rub preparations against live H1N1 influenza virus on the hands of human volunteers. Clin Infect Dis 48: 285-291, 2009.

15. Lombardi ME, Ladman BS, Alphin RL and Benson ER: Inactivation of avian influenza virus using common detergents and chemicals. Avian Dis 52: 118-123, 2008.

16. Alphin RL, Johnson KJ,Ladman BS and Benson ER: Inactivation of avian influenza virus using four common chemicals and one detergent. Poult Sci 88: 1181-1185, 2009.

17. Yamasaki H, Tsujimoto K, Koyama AH, Ejima D and Arakawa T: Arginine facilitates inactivation of enveloped viruses. J Pharm Sci 97: 3063-3073, 2008.

18. Katsuyama Y, Yamasaki H, Tsujimoto K, Koyama AH, Ejima D and Arakawa T: Butyroyl-arginine as a potent virus inactivation agent. Int J Pharm 361: 92-98, 2008.

19. Utsunimoya H, Ichinose M, Tsujimoto K, Katsuyama Y, Yamasaki H, Koyama AH, Ejima D and Arakawa T: Co-operative thermal inactivation of herpes simplex virus and influenza virus by arginine and NaCl. Int J Pharm 366: 99-102, 2009. 
20. Arakawa T, Kita Y and Koyama AH: Synergistic virus inactivation effects of arginine. Biotechnol J 4: 174-178, 2009.

21. Koyama AH and Uchida T: The effect of ammonium chloride on the multiplication of herpes simplex virus type 1 in Vero cells. Virus Res 13: 271-282, 1989.

22. Koyama AH, Irie H, Ueno F, Ogawa M, Nomoto A and Adachi A: Suppression of apoptotic and necrotic cell death by poliovirus. J Gen Virol 82: 2965-2972, 2001.

23. Kurokawa M, Koyama AH, Yasuoka S and Adachi A: Influenza virus overcomes apoptosis by rapid multiplication. Int J Mol Med 3: 527-530, 1999.

24. Racaniello VR: Picornaviridae: The viruses and their replication. In: Fields Virology. 4th edition. Fields BN, Knipe DM and Howley PM (eds.) Lippincott-Raven, New York, pp685-722, 2001.

25. Arakawa $\mathrm{T}$ and Tsumoto $\mathrm{K}$ : The effects of argnine on refolding of aggregated proteins: not facilitate refolding, but suppress aggregation. Biochem Biophys Res Commun 304: 148-152, 2003.

26. Tsumoto K, Ejima D, Kita $\mathrm{Y}$ and Arakawa T: Review: why is arginine effective in suppressing aggregation? Protein Pept Lett 12: 613-619, 2005

27. Arakawa T, Kita Y, Tsumoto K, Fukada H and Ejima D Aggregation suppression of proteins by arginine during thermal unfolding. Protein Pept Lett 13: 921-927, 2006.

28. Shiraki K, Kudou M, Fujiwara S, Imanaka T and Takagi M: Biophysical effect of amino acids on the prevention of protein aggregation. J Biochem 132: 591-595, 2002.

29. Tsumoto K, Umetsu M, Kumaga I, Ejima D and Arakawa T: Solubilization of active green fluorescent protein from insoluble particles by guanidine and arginine. Biochem Biophys Res Commun 312: 1382-1386, 2003.

30. Sakai N, Takeuchi T, Futaki S and Matile S: Direct observation of anion-mediated translocation of fluorescent oligoarginine carriers into and across liquid and anionic bilayer membranes. Chembiochem 6: 114-122, 2005.

31. Hirai A, Kawasaki H, Tanaka S, Nemoto N, Suzuki M and Maeda H: Effects of L-arginine on aggregate of fatty-acid/ potassium soap in the aqueous media. Colloid Polymer Sci 284: 520-528, 2006

32. Arakawa T, Philo JS, Tsumoto K, Yumioka R and Ejima D Elution of antibodies from a Protein-A column by aqueous arginine solution. Protein Expr Purif 36: 244-248, 2004.
33. Ejima D, Yumioka R, Tsumoto K and Arakawa T: Effective elution of antibodies by arginine and arginine derivatives in affinity column chromatography. Anal Biochem 345: 250-257, 2005.

34. Tsumoto K, Ejima D, Nagase K and Arakawa T: Arginine improves protein elution in hydrophobic interaction chromatography. The cases of human interleukin- 6 and activin-A. J Chromatogr A 1154: 81-86, 2007.

35. Ejima D, Yumioka R, Arakawa $\mathrm{T}$ and Tsumoto K: Arginine as an effective additive in gel permeation chromatography. J Chromatogr A 1094: 49-55, 2005.

36. Arakawa T, Tsumoto K, Nagase K and Ejima D: The effects of arginine on protein binding and elution in hydrophobic interaction and ion-exchange chromatography. Protein Expr Purif 54: 110-116, 2007.

37. Abe R, Kudou M, Tanaka Y, Arakawa T and Tsumoto K: Immobilized metal affinity chromatography in the presence of arginine. Biochem Biophys Res Commun 381: 306-310, 2009.

38. Futatsumori-Sugai M, Abe R, Watanabe M, Kudou M, Yamamoto T, Ejima D, Arakawa T and Tsumoto K: Utilization of Arg-elution method for FLAG-tag based chromatography. Protein Expr Purif 67: 148-155, 2009.

39. Hegardt FG. and Piė A: Sodium citrate salting-out of the human blood serum proteins. Rev Esp Fisiol 24: 161-168, 1968.

40. Kaushik JK and Bhat RA: Mechanistic analysis of the increase in the thermal stability of proteins in aqueous carboxylic salt solutions. Protein Sci 8: 222-233, 1999.

41. Stahlberg J, Jonsson B and Horvath C: Theory for electrostatic interaction chromatography of proteins. Anal Chem 63: 1867-1874, 1991.

42. Liapis AI and Grimes BA: The coupling of the electrostatic potential with the transport and adsorption mechanisms in ion-exchange chromatography systems: theory and experiments. J Sep Sci 28: 1909-1926, 2005

43. Traube J: The attraction pressure. J Phys Chem 14: 452-470, 1910.

44. Melander W and Horvath C: Salt effects on hydrophobic interactions in precipitation and chromatography of proteins: an interpretation of the lyotropic series. Arch Biochem Biophys 183: 200-215 1977

45. Roberts PL and Lloyd D: Virus inactivation by protein denaturants used in affinity chromatography. Biologicals 20: 1-5, 2007. 